\title{
KEDUDUKAN ARSIPARIS DALAM MELAKUKAN PENELITIAN, PENGKAJIAN DAN PENGEMBANGAN SISTEM KEARSIPAN
}

\author{
Drs. Bambang P. Widodo, M. Si. \\ Arsip Nasional Republik Indonesia \\ (wbambangparjono@yahoo.com)
}

\section{INTISARI}

Arsiparis dalam melakukan kegiatan penelitian/pengkajian bukanlah untuk melaksanakan tugas dan fungsi Arsiparis, tetapi lebih kepada tanggung jawab arsiparis sebagai tenaga fungsional untuk mencari kebenaran dan pengetahuan melalui cara-cara yang ilmiah. Arsiparis dengan penguasaan kegiatan pengelolaan arsip, baik dalam lingkup pekerjaan pengelolaan arsip dinamis maupun pengelolaan arsip statis, diharapkan mampu melakukan penelitian guna mengatasi perubahan yang terjadi dalam lingkungan kearsipan, baik yang disebabkan tuntutan pelayanan bagi kepentingan masyarakat ataupun perubahan yang disebabkan kemajuan teknologi dan komunikasi. Arsiparis sebagai tenaga fungsional dituntut bukan hanya profesional saja tetapi juga mampu menjadi archival scientist. Berbekal ilmu kearsipan yang dimilikinya, arsiparis yang melakukan penelitian diharapkan mampu menyempurnakan kebijakan kearsipan terhadap segala perubahan tentang hakekat arsip dan lingkungan pengelolaan kearsipan.

Kata Kunci: arsiparis, NSPK, peneliti, peneliti kearsipan, penelitian, pengembangan, pengkajian.

\begin{abstract}
Archivist in conducting research activities is not to carry out the dutties and functions of archivist, but rather to the responsibility of the archivist as a functional force to seek the truth and knowledge through scientific means. Archives with mastery of archive management activities, both within the scope of the work of archive management and static archive management, are expected to conduct research to overcome the changes occurring in archival environment, either caused by the demands of services for the benefit of society or changes caused by advances in technology and communication. Archivist as a functional force demanded not only professionals but also able to become archival scientist. With its archival science, the archivist who conducts the research is expected to be able to refine the archival policy to all changes about the archive nature and archive management environment.
\end{abstract}

Keywords: archival researcher, archives, assessment, development, research, researchers. 


\section{PENGANTAR}

Berlakunya Undang-Undang (UU) Nomor 43 Tahun 2009 tentang Kearsipan maupun Peraturan Pemerintah (PP) Nomor 28 Tahun 2012 tentang Pelaksanaan UndangUndang Nomor 43 Tahun 2009 tentang Kearsipan, telah mempengaruhi penyelenggaraan kearsipan secara nasional sehingga banyak hal yang perlu disiapkan guna mewujudkan tujuan penyelenggaraan kearsipan sebagaimana yang diamanatkan dalam Pasal 3 Undang-Undang Kearsipan. Beberapa 'policy' yang selama ini belum populer perlu dipahami secara utuh sehingga implementasinya dapat berjalan sesuai dengan harapan, sehingga mampu memberikan solusi khususnya dalam penyelenggaraan kearsipan.

Untuk memperoleh kedalaman materi terhadap aturan baru tersebut maka fungsi penelitian, pengkajian dan pengembangan sistem kearsipan seakan menjadi 'bumbu dapur' yang siap diolah sehingga menghasilkan suatu 'materi' yang mudah dipahami dan dimengerti oleh stakeholder maupun diaplikasikan oleh arsiparis maupun pelaku pengelola arsip pada setiap institusi/lembaga maupun organisasi.

Pasal 6 ayat (6) UU Nomor 43 Tahun 2009 tentang Kearsipan menyebutkan bahwa untuk mempertinggi mutu penyelenggaraan kearsipan nasional maka penyelenggara kearsipan nasional - Arsip Nasional Republik Indonesia (ANRI) melakukan penelitian dan pengembangan serta penyelenggaraan pendidikan dan pelatihan kearsipan. Dalam melakukan penelitian dan pengembangan kearsipan maka sesuai Peraturan Kepala ANRI Nomor : 14 Tahun 2014 tentang Organisasi dan Tata kerja Arsip Nasional Republik Indonesia dilakukan oleh Pusat Pengkajian dan Pengembangan Sistem Kearsipan. Unit ini merupakan segala kebijakan kearsipan nasional termasuk dalam bentuk Norma, Standar, Pedoman, dan Ketentuan (NSPK) dihasilkan. Sementara penyelenggaraan kearsipan di wilayah provinsi, kabupaten/kota dan perguruan tinggi menjadi tanggung jawab lembaga kearsipan masing-masing sesuai dengan kewenangannya, karena biar bagaimanapun NSPK yang dihasilkan dan sifatnya lokal/kewilayahan menjadi tanggung jawabnya.

Guna memaksimalkan kualitas 'materi' dari hasil penelitian, pengkajian dan pengembangan sistem kearsipan, maka diperlukan dukungan sumber daya manusia yang mempunyai kompetensi dalam melakukan pengkajian dan pengembangan sistem kearsipan, termasuk keberadan arsiparis yang menjalankan peran dan fungsi untuk melakukan penelitian, pengkajian dan pengembangan. Arsiparis yang dimaksud bukan sekedar jabatannya sebagai arsiparis saja, tetapi arsiparis yang mempunyai kualifikasi tidak hanya menguasai 'materi' kearsipan namun juga didukung oleh kemampuan dalam menyusun suatu standar/pedoman kearsipan, dan juga kemampuannya dalam melakukan penelitian ataupun pengkajian. 


\section{Permasalahan}

Pentingnya kemampuan melakukan penelitian bagi arsiparis merupakan kebutuhan riil dan jangan diartikan sebagai 'pemaksaan' terhadap tugas dan fungsinya dalam melakukan pekerjaan kearsipan, mengingat dalam Peraturan Menteri Pendayagunaan Aparatur Negara dan Reformasi Birokrasi (PERMENPAN RB) Nomor: 13 Tahun 2016 tentang Perubahan atas Peraturan Menteri Pendayagunaan Aparatur Negara dan Reformasi Birokrasi Nomor 48 Tahun 2014 tentang Jabatan Fungsional Arsiparis, dengan jelas disebutkan bahwa tugas pokok arsiparis saat ini adalah melakukan pengelolaan arsip dinamis, pengelolaan arsip statis, pembinaan kearsipan, serta pengolahan dan penyajian arsip menjadi informasi. Artinya, bagi arsiparis kegiatan melakukan penelitian dan pengkajian kearsipan bukan lagi menjadi tugas pokok arsiparis menjadi unsur pengembangan profesi sebagaimana yang terdapat dalam Pasal 4 PERMENPAN Nomor: Per/3/M.PAN/3/2009 tentang Jabatan Fungsional Arsiparis dan Angka Kreditnya.

Sementara seperti kita ketahui, dalam membuat karya tulis/karya ilmiah di bidang kearsipan mensyaratkan adanya hasil penelitian, pengkajian, survei dan evaluasi, yang kesemuanya itu memerlukan cara-cara ilmiah untuk memperoleh data, informasi dengan tujuan dan kegunaan tertentu. Hasil penelitian yang dilakukan arsiparis merupakan suatu karya tulis/karya ilmiah di bidang kearsipan yang disusun secara metodologis ini merupakan kegiatan yang selama ini diakui sebagai unsur dalam pengembangan profesi arsiparis, begitupun dengan kegiatan penyusunan NSPK.
Kemampuan arsiparis untuk melakukan penelitian/pengkajian merupakan entry-point untuk melakukan pembuatan/penyusunan ataupun penyempurnaan terhadap NSPK di bidang kearsipan. Berkurangnya arsiparis dalam melakukan penelitian dan pengkajian terhadap penyelenggaraan kearsipan akibat kegiatan tersebut bukan lagi menjadi tugas pokok arsiparis, akankah berimbas kepada kualitas dari penyelenggaraan kearsipan? Demikian pula, apakah arsiparis dalam melakukan penelitian dan pengkajian terhadap penyelenggaraan kearsipan dapat bersinggungan dengan fungsional peneliti?

Berdasarkan uraian di atas, maka tulisan ini mencoba mendudukkan peran dan kontribusi arsiparis yang melakukan penelitian dan pengkajian terhadap penyelenggaraan kearsipan, serta mencari titik temu antara dualisme fungsional arsiparis dengan peneliti, sehingga kehadiran arsiparis dalam melakukan kegiatan penelitian/pengkajian mampu mengejawantahkan UU Nomor 43 Tahun 2009 tentang Kearsipan.

Metode penulisan ini sepenuhnya dilakukan secara deskriptif kualitatif dengan mendeskripsikan tentang gejala yang terjadi pada objek sesuai fokus permasalahan. Pendekatan penelitian menggunakan pendekatan naturalistik untuk meneliti kondisi objek yang alami, yaitu tugas, fungsi, dan kewenangan arsiparis. Pengumpulan data dilakukan melalui studi pustaka, baik data primer dan sekunder sehingga mampu memperjelas berbagai hal yang ditemukan dalam penelitian kualitatif. Observasi dilakukan dengan mengamati pekerjaan yang dilakukan arsiparis serta pengalaman penulis selama lebih 20 tahun menduduki jabatan fungsional arsiparis. 
Teknik analisis data yang digunakan adalah teknik analisis isi (content analysis) dimana proses analisis data dimulai sejak sebelum dan selama proses di lapangan (model spradley) yang kemudian dituangkan dalam bentuk narasi deskriptif dan membuat rangkuman inti secara induktif.

Berdasarkan tujuan, tulisan ini digolongkan sebagai penelitian deskriptif (descriptive research) karena memberikan gambaran yang lebih rinci mengenai suatu gejala dan fenomena tugas dan fungsi arsiparis dalam melakukan penelitian dan pengembangan sistem penyelenggaraan kearsipan. Apabila ditinjau dari segi manfaat, penelitian ini digolongkan sebagai penelitian terapan (applied research) karena penelitian ini diharapkan mampu menyelesaikan masalah secara spesifik.

\section{PEMBAHASAN}

\section{Arsiparis dan Pengembangan Profesi}

Kegiatan pengembangan profesi arsiparis sebagaimana yang tertuang dalam PERMENPAN Nomor 3 Tahun 2009 tersebut antara lain:(A) membuat karya tulis/karya ilmiah di bidang kearsipan; (B) menyusun standar/pedoman kearsipan; (C) menemukan teknologi tepat guna di bidang kearsipan; (D) uji kompetensi; dan (E) penerjemahan/penyaduran buku dan bahan lainnya di bidang kearsipan.

Selama ini banyak arsiparis memanfaatkan pengembangan profesi ini untuk memperoleh angka kredit yang optimal, hal ini dikarenakan dalam persyaratan untuk dapat naik pangkat dan jabatan pada jenjang jabatan tertentu (arsiparis madya dan arsiparis utama) mewajibkan mendapatkan angka kredit minimal untuk kegiatan pengembangan profesi ini. Berdasarkan database sekretariat tim penilai instansi pembina pada periode 2014 s.d. 2016 diperoleh hasil sebagai berikut:

Tabel 1

Jenis Kegiatan Pengembangan Profesi

dari Jenjang Jabatan Arsiparis Madya Periode 2014 s.d. 2016

\begin{tabular}{|c|l|c|c|c|c|c|}
\hline \multirow{2}{*}{ NO. } & INSTANSI & \multicolumn{5}{|c|}{ KEGIATAN PENGEMBANGAN PROFESI } \\
\cline { 3 - 7 } & & (A) & (B) & (C) & (D) \\
\hline & & & & - & 22 & 7 \\
2 & Lembaga Kearsipan & 12 & 21 & - & 12 & - \\
3 & Kementerian & 2 & 4 & - & 9 & - \\
4 & Lembaga Negara & - & 4 & - & 16 & 2 \\
5 & Pemerintah Daerah & 2 & 17 & - & 7 & - \\
\hline
\end{tabular}

Sumber: Sekretariat Tim Penilai Instansi Pembina (Data yang Diolah, 2017) 
Tabel di atas menunjukkan kegiatan menyusun pedoman/standar kearsipan (B) merupakan kegiatan pengembangan profesi kearsipan yang paling diminati oleh arsiparis madya, sementara membuat karya tulis di bidang kearsipan (A) menduduki peringkat berikutnya. Namun, baik itu jumlah arsiparis madya yang menyusun pedoman/standar kearsipan (B) dan membuat karya tulis di bidang kearsipan (A) masih di bawah dari kegiatan arsiparis madya yang mengikuti uji kompetensi.

Hal ini membuktikan bahwa kegiatan pengembangan profesi kearsipan khususnya kegiatan (A) sebagai bentuk kegiatan penelitian kearsipan dan kegiatan (B) sebagai bentuk pengembangan profesi menjadi jalur alternatif arsiparis untuk memperoleh angka kredit. Hal lain, yang menjadi daya tarik untuk melakukan kegiatan (A) dan (B) adalah nilai angka kredit dari dua jenis kegiatan tersebut cukup tinggi. Terlebih, adanya kewajiban bagi instansi untuk menyusun 4 (empat) instrumen pengelolaan arsip dinamis setidaknya mampu mendorong arsiparis untuk mampu menyelesaikan tepat waktu.

\section{Fungsi dan Tugas Arsiparis}

Pasal 8 ayat (1) PERMENPAN RB Nomor 48 Tahun 2014 tentang Jabatan Fungsional Arsiparis, menyebutkan tugas pokok arsiparis adalah melaksanakan kegiatan pengelolaan arsip dinamis, pengelolaan arsip statis, pembinaan kearsipan, dan pengolahan dan penyajian arsip menjadi informasi. Tugas pokok ini mengamanatkan perlunya arsiparis menguasai semua kegiatan pengelolaan arsip, baik dalam lingkup pekerjaan pengelolaan arsip dinamis maupun pengelolaan arsip statis, mulai dari mengolah sampai dengan arsip sebagai suatu informasi, termasuk melakukan pembinaan kearsipan sesuai dengan kompetensi dan kewenangan yang dimilikinya.

Pengelolaan arsip dan pembinaan kearsipan sebagai unsur utama kegiatan kearsipan harus dilakukan oleh arsiparis sesuai dengan tugas dan fungsi arsiparis sebagaimana yang dimaksud dalam Pasal 151 ayat (2) PP Nomor 28 Tahun 2012 tentang Pelaksanaan Undang-Undang Nomor 43 Tahun 2009 tentang Kearsipan, yang meliputi :

1. Menjaga terciptanya arsip dari kegiatan yang dilakukan oleh lembaga negara, pemerintahan daerah, lembaga pendidikan, perusahaan, organisasi politik, dan organisasi kemasyarakatan;

2. Menjaga ketersediaan arsip yang autentik dan terpercaya sebagai alat bukti yang sah;

3. Menjaga terwujudnya pengelolaan arsip yang andal dan pemanfaatan arsip sesuai dengan ketentuan peraturan perundangundangan;

4. Menjaga keamanan dan keselamatan arsip yang berfungsi untuk menjamin arsip-arsip yang berkaitan dengan hak-hak keperdataan rakyat melalui pengelolaan dan pemanfaatan arsip yang autentik dan terpercaya;

5. Menjaga keselamatan dan kelestarian arsip sebagai bukti pertanggungjawaban dalam kehidupan bermasyarakat, berbangsa, dan bernegara;

6. Menjaga keselamatan aset nasional dalam bidang ekonomi, sosial, politik, budaya, pertahanan, serta keamanan sebagai identitas dan jati diri bangsa; dan 
7. Menyediakan informasi guna meningkatkan kualitas pelayanan publik dalam pengelolaan dan pemanfaatan arsip yang autentik dan terpercaya.

Berdasarkan komponen di atas, jelas arsiparis hanya terkonsentrasi terhadap kegiatan pengelolaan kearsipan beserta kewenangan yang ditimbulkan dari adanya tugas dan fungsi arsiparis. Sementara dalam PERMENPAN RB Nomor 48 Tahun 2014 tentang Jabatan Fungsional Arsiparis, tidak ada lagi unsur kegiatan pengembangan profesi arsiparis. 
Tabel 2

Posisi Kegiatan Penelitian/Pengkajian dalam PERMENPAN No. Per/3.M.PAN/3/2009

dengan PERMENPAN RB No. 48 Tahun 2014

\begin{tabular}{|c|c|}
\hline $\begin{array}{c}\text { PERMENPAN } \\
\text { NOMOR:PER/3/M.PAN/3/2009 }\end{array}$ & PERMENPAN DAN RB NOMOR 48 TAHUN 2014 \\
\hline $\begin{array}{l}\text { UNSUR UTAMA: } \\
\text { 1. Pendidikan } \\
\text { 2. Pengelolaan Arsip } \\
\text { 3. Pembinaan Kearsipan } \\
\text { 4. Pengembangan Profesi Kearsipan: } \\
\text { a. Membuat karya tulis/karya ilmiah } \\
\text { (hasil penelitian) } \\
\text { b. Menyusun standar/pedoman } \\
\text { kearsipan } \\
\text { c. Menemukan teknologi tepat guna di } \\
\text { bidang kearsipan } \\
\text { d. Uji Kompetensi } \\
\text { e. Menerjemahkan/menyadur buku dan } \\
\text { bahan lainnya di bidang kearsipan } \\
\text { UNSUR PENUNJANG }\end{array}$ & 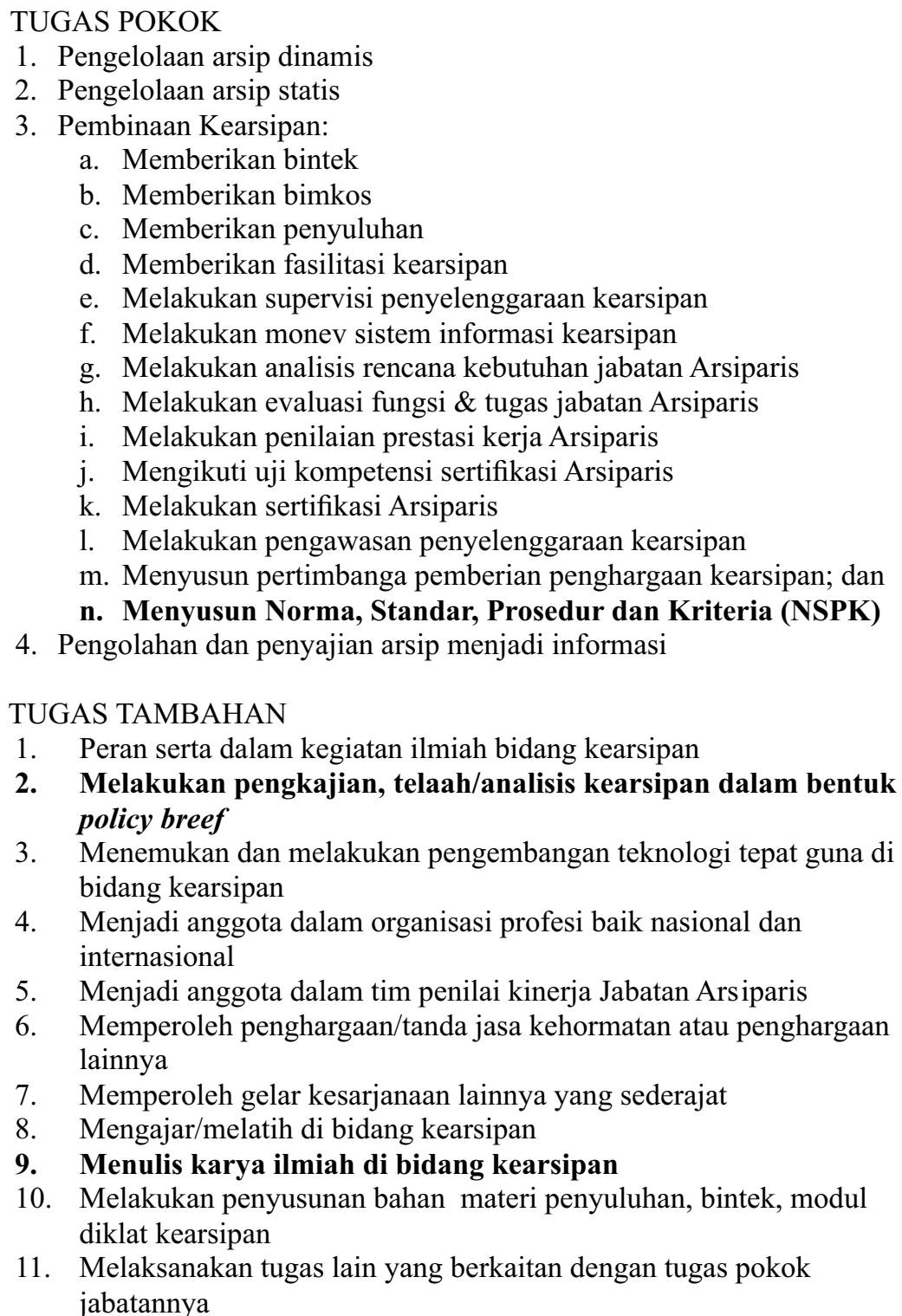 \\
\hline
\end{tabular}


Kegiatan pengembangan profesi arsiparis tersebut, terdapat beberapa kegiatan yang tidak lagi menjadi tugas pokok arsiparis, yaitu (1) membuat karya tulis/karya ilmiah di bidang kearsipan; dan (2) menemukan teknologi tepat guna di bidang kearsipan. Kegiatan ini tidak lagi menjadi tugas pokok arsiparis karena semata-mata untuk memisahkan fungsi dari jabatan fungsional arsiparis dengan jabatan fungsional peneliti dimana kegiatan penelitian dan pengkajian merupakan tugas pokok dari fungsional peneliti.

Perubahan tugas pokok arsiparis dalam melakukan kegiatan penelitian berbentuk karya ilmiah di bidang kearsipan dan melakukan kajian hanyalah menjadi tugas tambahan arsiparis sehingga pekerjaan tersebut tidak diakui lagi sebagai tugas pokok arsiparis. $\quad \mathrm{N}$ a m u n demikian, meskipun kegiatan penelitian dan pengkajian bukan lagi menjadi tugas pokok arsiparis, setiap arsiparis tetap masih diberi kesempatan untuk mengembangkan keahlian dan keterampilan sesuai dengan kompetensi yang dimilikinya namun kegiatan yang dilakukan hanya merupakan tugas tambahan. Oleh karena itu, kegiatan penelitian dan pengkajian dalam bentuk penulisan karya tulis/karya ilmiah bagi arsiparis menjadi hanya tugas tambahan sebagaimana dalam Pasal 8 ayat (4) PERMENPAN RB Nomor 48 Tahun 2014 tentang Jabatan Fungsional Arsiparis, sementara untuk penyusunan Norma, Standar, Prosedur dan Kriteria (NSPK) tetap dikelompokkan sebagai tugas pokok dalam melakukan pembinaan kearsipan.

Seperti kita ketahui, UU Kearsipan telah mengamanatkan bahwa setiap pencipta arsip dalam melakukan pengelolaan arsip dinamisnya perlu menyiapkan (empat) instrumen pendukung dalam pengelolaan arsip dinamis, sebagaimana yang diamanatkan dalam Pasal 40 ayat (4) UU Nomor 43 Tahun 2009 tentang Kearsipan, yaitu Tata Naskah Dinas, Klasifikasi Arsip, Jadwal Retensi Arsip, dan Sistem Klasifikasi Keamanan dan Akses Arsip. Instrumen pendukung ini merupakan penyusunan NSPK yang harus disiapkan oleh pencipta arsip.

Ketersediaan 4 (empat) instrumen pokok pengelolaan arsip dinamis dalam bentuk NSPK tersebut, memiliki signifikansi dalam menjamin autentisitas dan reliabilitas arsip dinamis yang tercipta, menjamin ketepatan pemberkasan arsip aktif pada unit pengolah dan penataan arsip inaktif pada unit kearsipan, menjamin akuntabilitas pemindahan arsip inaktif dari unit pengolah ke unit kearsipan, pemusnahan yang tidak memiliki nila guna, dan penyerahan arsip statis dari pencipta arsip ke lembaga kearsipan dalam rangka penyelamatan arsip statis sebagai memori kolektif, serta menjamin keamanan akses dan keselamatan arsip aktif dan arsip inaktif dari penggunaan oleh pihak yang tidak berhak dan kebocoran informasi.

Pasal 1 angka 27 UU Nomor 43 Tahun 2009 tentang Kearsipan menyebutkan pengelolaan arsip dinamis adalah proses pengendalian arsip dinamis secara efisien, efektif, dan sistematis meliputi penciptaan, penggunaan dan pemeliharaan, serta penyusutan arsip. Pengelolaan arsip ditujukan untuk menjamin ketersediaan arsip dalam penyelenggaraan kegiatan sebagai bahan akuntabilitas kinerja dan alat bukti yang sah. 


\section{Penelitian, Pengkajian dan Pengembangan}

Manusia adalah makhluk yang mempunyai sifat dasar 'ingin tahu' dan 'mencari kebenaran', untuk mencari pengetahuan yang benar hanya dapat diketemukan bila dilakukan dengan cara-cara atau aturan tertentu. Aturan tertentu inilah yang disebut ilmu, sementara sesuatu yang memungkinkan digunakannya ilmu dinamakan ilmiah. Ilmu yang diperoleh dari hasil penelitian itulah yang dinamakan ilmu pengetahuan (Talizuduhu Ndraha: 1989, 19).

Istilah penelitian dalam konteks pemakai seringkali digunakan secara bergantian dengan istilah pengkajian. Hal ini banyak dijumpai di beberapa kantor instansi pemerintah yang menggunakan istilah 'pengkajian' selain penelitian. Peraturan Kepala Lembaga Ilmu Pengetahuan Indonesia (LIPI) Nomor 06/E/2013 tentang Kode Etik Peneliti, menyebutkan penelitian sebagai kegiatan yang dilakukan menurut kaidah dan metode ilmiah secara sistematis untuk memperoleh informasi, data dan keterangan yang berkaitan dengan pemahaman dan pembuktian kebenaran atau ketidakbenaran suatu asumsi dan atau hipotesis di bidang iptek serta menarik kesimpulan ilmiah bagi keperluan kemajuan iptek. Pengertian ini sejalan dengan pendapat yang dikemukakan oleh Sugiyono (2008;2), bahwa penelitian pada dasarnya merupakan cara ilmiah untuk mendapatkan data dengan tujuan dan kegunaan tertentu.

Penelitian menurut Sutrisno Hadi dalam Talizuduhu Ndraha $(1990,2)$ diartikan sebagai
“... usaha untuk menemukan, mengembangkan, menguji kebenaran suatu pengetahuan; usaha mana dilakukan dengan menggunakan metodemetode ilmiah."

Dengan demikian penelitian dapat diartikan sebagai usaha untuk menemukan (pengetahuan) sesuatu hal menurut metode ilmiah. Ciri utama metode ilmiah adalah bersifat empiris (berdasarkan pengalaman), artinya segala keputusan yang diambil berdasarkan pengalaman, data telah diperiksa kebenarannya, dan keputusan yang diambil cocok dengan kenyataan.

Sementara pengertian pengkajian dipahami sebagai suatu kegiatan yang cakupannya lebih luas dari penelitian. Dalam pengkajian, tidak hanya kegiatan penelitian/riset saja tetapi juga ada kegiatan lain seperti: analisis, telaah, studi maupun penyelidikan. Kegiatan-kegiatan tersebut tetap menggunakan cara-cara ilmiah namun bukan untuk mencari data tetapi justru untuk menarik kesimpulan dari informasi yang telah diperolehnya. Penggunaan istilah 'pengkajian' dirasakan lebih cocok untuk suatu unit kerja yang mempunyai tugas untuk merumuskan kebijakan, termasuk kebijakan di bidang kearsipan. Analisis kebijakan memerlukan sebuah uraian data, informasi dan berbagai alternatif untuk menentukan sebuah kebijakan, demikian menurut Abdul Kadir Badjuri dan Teguh Yuwono (2002, 66). Itu artinya, suatu kebijakan dapat dirumuskan melalui analisis ataupun telaah tanpa harus melalui penelitian. 
Kegiatan yang melekat dengan penelitian ataupun pengkajian adalah pengembangan kearsipan. LIPI telah mendefinisikan pengembangan sebagai kegiatan ilmu pengetahuan dan teknologi (iptek) yang bertujuan memanfaatkan kaidah dan teori ilmu pengetahuan yang terbukti kebenarannya untuk meningkatkan fungsi, manfaat, dan aplikasi iptek yang telah ada, atau menghasilkan teori baru. Pengembangan diartikan sebagai bentuk penyempurnaan terhadap suatu 'teori' atau kebijakan yang telah ada sebelumnya, dan pengembangan tidak akan dilakukan jika belum ada 'teori' atau kebijakan. Sisi lain pengembangan berarti mengembangkan penelitian dan hasil-hasil penelitian, baik sebagai pengetahuan maupun teknologi.

Penggunaan nama penelitian dan pengembangan (litbang) dalam konteks kelembagaan, umumnya lebih banyak digunakan untuk satuan kerja instansi yang sifatnya teknis. Hal ini berbeda dengan instansi yang bersifat non teknis, mereka lebih menggunakan nomenklatur kelembagaannya dengan nama pengkajian dan pengembangan (jibang). Penelitian dan pengembangan merupakan suatu proses, demikian pula pengkajian dan pengembangan. Proses yang dimaksud memberikan hasil akhir berupa penemuan, rekomendasi dan sebagainya, sebagaimana tugas dan fungsi pada Pusat Pengkajian dan Pengembangan Sistem KearsipanANRI.

\section{Arsiparis sebagai Peneliti}

Arsiparis dan peneliti merupakan jabatan fungsional yang disandang oleh pegawai negeri sipil (PNS). Jika arsiparis mengkhususkan kepada kegiatan kearsipan, sementara peneliti sesuai pengertian dalam Peraturan Kepala LIPI Nomor 02 Tahun 2014 tentang Petunjuk Teknis Jabatan Fungsional Peneliti, adalah PNS yang diberi tugas, tanggung jawab, wewenang dan hak secara penuh oleh pejabat berwenang untuk melakukan penelitian dan/atau pengembangan iptek pada satuan organisasi, serta penelitian dan pengembangan pada instansi pemerintah.

Tugas utama peneliti adalah melakukan penelitian dan pengembangan iptek. Sementara bagi arsiparis, kegiatan penelitian dan pengembangan merupakan wadah untuk mengembangkan profesinya diluar pekerjaan sehari-hari pada unit kerjanya maupun diluar unit kerjanya. Itu artinya, arsiparis diberikan kesempatan untuk memberikan kontribusi sesuai kemampuannya melalui kegiatan penelitian, pengkajian ataupun pengembangan sistem kearsipan. Dengan kata lain, penelitian dapat dilakukan oleh siapapun, termasuk oleh arsiparis. 
Ketika seorang arsiparis berperan sebagai peneliti maka ilmu kearsipan yang dimiliki arsiparis harus dipadukan dengan kemampuan dalam melakukan penelitian ilmiah, karena mutlak dalam melakukan penelitian diperlukan penguasaan yang baik mengenai hakekat keilmuan sebagaimana yang diutarakan Jujun S. Suriasumantri (1989, 19). Hakekat keilmuan yang dimaksud adalah disiplin-disiplin pengetahuan yang membangun dasar-dasar dari teori penelitian. Oleh karena itu, penelitian tidak bisa dipisahkan dari dunia ilmu pengetahuan. Kearsipan dikatakan sebagai ilmu menyaratkan tiga hal, sebagaimana yang ciri-ciri ilmu yang didasarkan atas jawaban: ontologi, epistemologi, dan aksiologi. Ontologi memperlihatkan objek kajian kearsipan, epistemologi menunjukan cara memperoleh pengetahuan, dan aksiologi memperlihatkan kemanfaatan kearsipan bagi kehidupan manusia. Dengan demikian, penguasaan metodologi dalam melakukan penelitian ilmiah bagi arsiparis akan berdampak kepada hasil penelitian.

Peran arsiparis sebagai peneliti dalam melakukan penelitian, pengkajian, dan pengembangan di bidang kearsipan dimulai sejak arsiparis menyiapkan rancangan penelitian (proposal) dan penyusunan instrumen penelitian. Penyusunan instrumen penelitian di bidang kearsipan dalam penelitian kuantitatif pada umumnya belum tersedia dan teruji. Oleh karena itu, arsiparis dapat merumuskan variabel dan indikator yang akan diukur sesuai dengan lingkup tahapan kegiatan kearsipan.
Sementara untuk penelitian kualitatif, justru arsiparislah yang berperan karena perannya sebagai peneliti. Menurut Lincoln dan Guba (2009, 223), dalam penelitian kualitatif instrumen utamanya adalah peneliti. Oleh karena itu, peneliti sebagai instrumen harus 'divalidasi', meliputi validasi terhadap pemahaman metode penelitian kualitatif, penguasaan wawasan terhadap bidang kearsipan yang diteliti, kesiapan peneliti untuk memasuki objek penelitian. Dengan demikian, apabila arsiparis berperan sebagai peneliti maka arsiparis juga sebagai instrumen utama dari kegiatan penelitian. Arsiparis sebagai human instrument berfungsi menetapkan fokus penelitian, memilih informasi sebagai sumber data, melakukan pengumpulan data, analisis data dan membuat kesimpulan.

Arsiparis pada saat melakukan penelitian dan pengkajian Sistem Kearsipan acap kali dihadapkan dengan pilihan dalam melakukan penelitian, terutama untuk menentukan metode penelitian kuantitatif atau penelitian kualitatif. Penelitian kuantitatif atau metode tradisional merupakan metode yang sudah mentradisi sebagai metode untuk penelitian. Menurut Borg and Gall dalam Sugiyono (2008, 9), metode ini berlandaskan kepada metode positivistik (filsafat positivisme). Filsafat positivisme memandang realitas/gejala/fenomena itu dapat diklasifikasikan, relatif tetap, konkrit, teramati, terukur, dan hubungan gejala bersifat sebab akibat. Penelitian kuantitatif umumnya dilakukan pada populasi atau sampel tertentu yang representatif dan ditentukan secara random. 
Oleh karena ingin bebas nilai, maka peneliti menjaga jarak dengan sumber data supaya data yang diperoleh obyektif. Instrumen penelitian digunakan untuk mengumpulkan data, selanjutnya data yang terkumpul dianalisis secara kuantitatif dengan menggunakan statistik deskriptif. Proses penelitian kuantitatif bersifat deduktif, kesimpulan diambil sesuatu yang bersifat umum ke sesuatu yang bersifat khusus.

Sementara dalam penelitian kualitatif seringkali disebut metode modern/baru. Metode ini menurut Susan Stainback dalam Sugiyono (2008, 14) berlandaskan kepada metode postpositivistik karena berlandaskan pada filsafat postpositivisme, yaitu memandang realitas sosial sebagai sesuatu yang utuh, kompleks, dinamis, penuh makna, dan hubungan gejala bersifat interaktif. Cara yang digunakan adalah melakukan in-dept interview dimana peneliti berperan sebagai instrumen penelitian. Penarikan kesimpulan bersifat induktif, berangkat dari hal-hal yang bersifat khusus menuju hal-hal yang bersifat umum.
Dalam konteks arsiparis sebagai peneliti maka penelitian kualitatif yang berlandaskan postpositivism lebih 'pas' diterapkan. Ini sejalan dengan pemikiran Erick Ketelaar dan Oddo Bucci (Noerhadi Magetsari; 2008, 5-6) yang mengemukakan bahwa pengembangan kearsipan sebagai ilmu cenderung untuk lebih berupaya memahami dan menerima berbagai perbedaan sehingga mampu mengembangkan teori tentang ilmu kearsipan. Konsep ini mencoba memadukan antara pengetahuan kearsipan dengan ilmu kearsipan. Pengetahuan kearsipan membuka jalan suatu ilmu kearsipan, dan sebaliknya ilmu kearsipan senantiasa mengembangkan pengetahuan kearsipan. Konsep ini bertentangan dengan pendapat Luciana Durranti yang menganut positivism, pentingnya ilmu kearsipan melalui penekanan pada teori dan metodologi yang mendasari praktek. Kearsipan sebagai suatu ilmu haruslah menerapkan metode yang bersifat universal, yaitu metode science. 


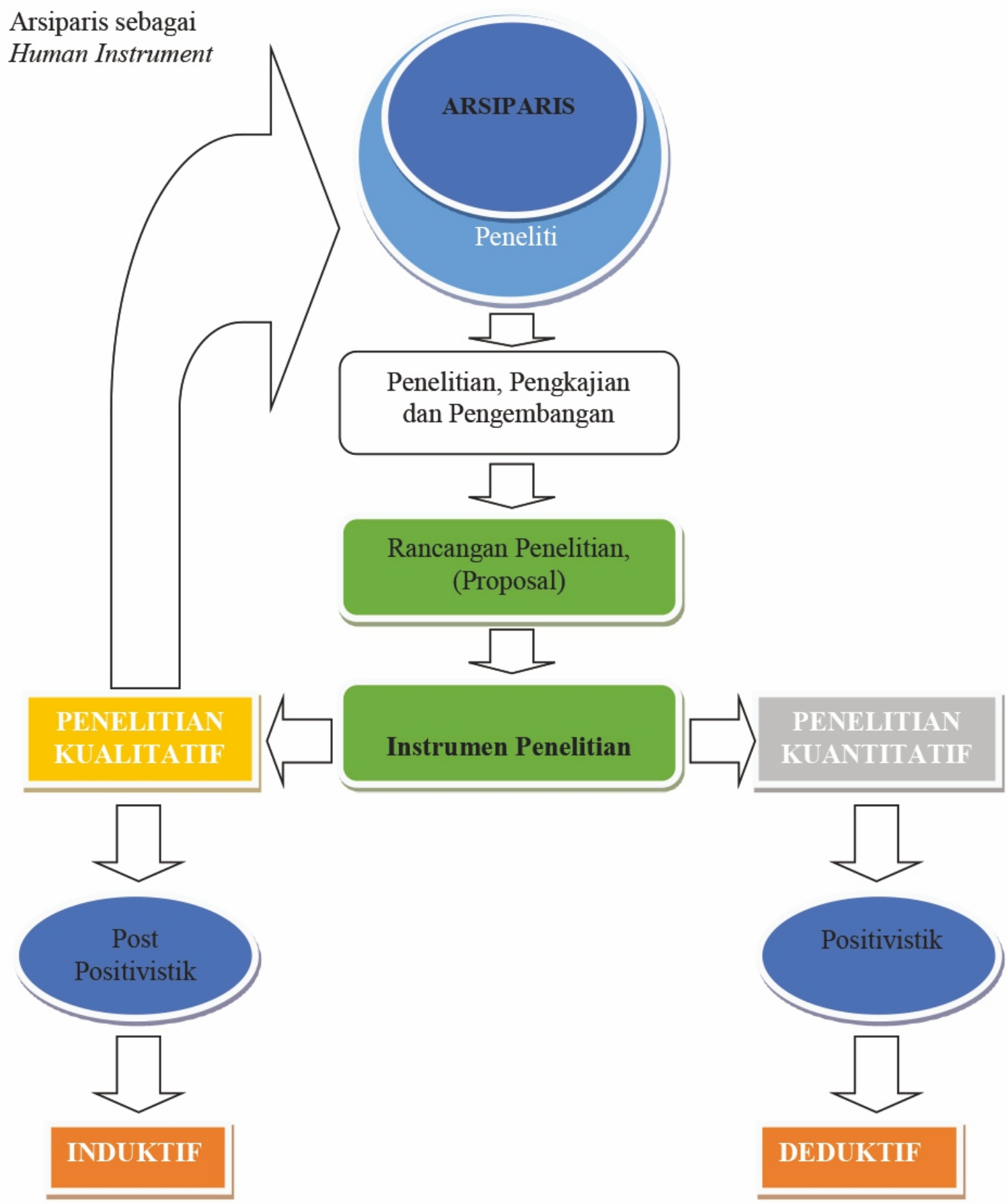

Gambar 1

Arsiparis sebagai Peneliti 
Penelitian kualitatif dilakukan pada kondisi yang alamiah, langsung ke sumber data dan arsiparis sebagai peneliti adalah instrumen kunci. Peneliti ikut berpartisipasi lama di lapangan, mencatat hal-hal yang terjadi, dan melakukan analisis terhadap temuan di lapangan. Penelitian kualitatif lebih menekankan kepada proses daripada produk, hasilnya akan memiliki kualitas ilmiah yang lebih sesuai dengan salah satu perannya dalam menyusun suatu NSPK bidang kearsipan.

Kendala di lapangan adalah pertimbangan praktis lebih mengemuka akibat terbatasnya waktu, anggaran, dan SDM maupun kemudahan lainnya, maka penelitian kuantitatif kerap dipilih dalam penelitian. Pertimbangan ideal mengenai sampel yang besar dapat diatasi dengan pembatasan populasi, dimana populasi penelitian kearsipan menitikberatkan kepada jumlah provinsi dan bukan kabupaten/kota. Keterpenuhan syarat sampel sejumlah minimal 29 provinsi dari 33 provinsi (sesuai tabel penentuan jumlah sampel dari populasi tertentu dengan taraf kesalahan 1\%, 5\%, dan 10\% oleh Issac dan Michael) dapat diatasi dengan metode survei ataupun mengirimkan angket/kuesioner melalui pos ke tiap-tiap provinsi.
Sementara dalam penyusunan dan penyempurnaan NSPK, arsiparis tidak melakukan penelitian secara utuh tetapi lebih kepada observasi langsung di lapangan dan melakukan in-dept interview berdasarkan kebutuhan yang dirancang dalam melakukan penyusunan NSPK. Persoalan akan muncul ketika akan menyusun suatu NSPK tidak didukung dengan sumber dana, sehingga mengakibatkan yang dijadikan sumber informan akhirnya lebih kepada informan yang berasal dari instansi lokal ataupun pemerintah daerah. Padahal seyogyanya informasi akan lebih sempurna apabila diperoleh dari institusi/lembaga yang memiliki kredibilitas dan pengakuan secara internasional.

Hasil dari penelitian/pengkajian ditindaklanjuti dengan penyusunan NSPK. Selanjutnya dalam suatu periode tertentu maka dilakukan evaluasi dalam bentuk pengkajian terhadap NSPK yang telah disusun sebelumnya. Hasil pengkajian merekomendasikan perlu atau tidaknya pengembangan NSPK. Apabila dipandang perlu maka dilakukanlah kegiatan penyempurnaan terhadap NSPK. Untuk lebih jelasnya dapat dilihat dari alir bagan berikut ini ini. 


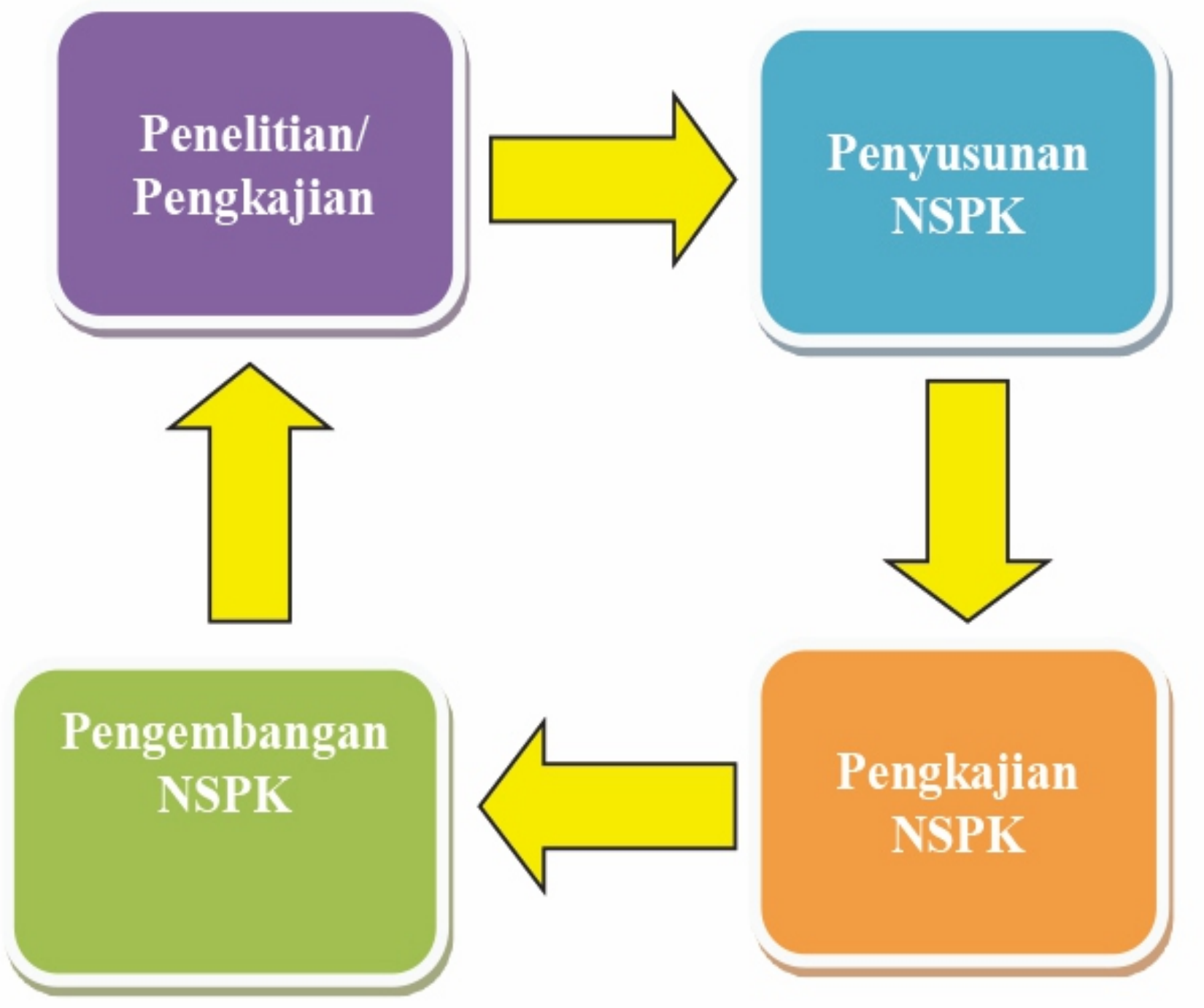

Gambar 2

Alur Penyusunan NSPK 


\section{KESIMPULAN}

Berdasarkan penjelasan tersebut maka dapat disimpulkan:

1. Keberadaan arsiparis dalam melaksanakan penelitian/pengkajian pada saat ini bukanlah untuk melaksanakan tugas pokok dan fungsi arsiparis, tetapi lebih kepada tanggung jawab arsiparis sebagai tenaga fungsional yang dilatarbelakangi oleh kemauan untuk mencari kebenaran dan pengetahuan melalui cara-cara ilmiah;
2. Arsiparis sebagai tenaga fungsional dituntut bukan hanya profesional dalam melaksanakan tugas pokok di bidang kearsipan saja tetapi juga mampu berperan sebagai peneliti kearsipan (archival scientist) sebagai titik temu yang menghubungkan antara tugas pokok arsiparis dengan peneliti. Berbekal ilmu kearsipan yang dimilikinya, arsiparis yang melakukan penelitian diharapkan mampu beradaptasi terhadap segala perubahan tentang hakekat arsip dan lingkungan pengelolaan kearsipan. 


\section{DAFTAR PUSTAKA}

Badjuri, Abdulkahar (dan), Yuwono, Teguh, 2002. Kebijakan Publik; Konsep dan Strategi. JIP Universitas Diponegoro, Semarang.

Denzin, Norman, K (and) Lincoln Yvonna, S., 2009. Hand Book of Qualitative Research.Pustaka Pelajar, Yogyakarta.

Ndraha, Talizuduhu, 1989. Research; Teori Metodologi Administrasi. PT. Bina Aksara, Jakarta.

Sugiyono, 2008. Metode Penelitian Kuantitatif Kualitatifdan $R \& D$. Alfabeta, Bandung.

Suriasumantri, Jujun, S, 1987. Filsafat Ilmu, Sebuah Pengantar Populer. Sinar Harapan, Jakarta.

\section{Peraturan}

Undang-Undang Republik Indonesia Nomor 43 Tahun 2009 tentang Kearsipan.

Peraturan Pemerintah Republik Indonesia Nomor 28 Tahun 2012 tentang Pelaksanaan Undang-Undang Nomor 43 Tahun 2009 tentang Kearsipan.

Peraturan Menteri Pendayagunaan Aparatur Negara Nomor: PER/ 3/ M.PAN/ 3/ 2009 tentang Jabatan Fungsional Arsiparis dan Angka Kreditnya.

Peraturan Menteri Pendayagunaan Aparatur Negara dan Reformasi Birokrasi Nomor : 48 Tahun 2014 tentang Jabatan Fungsional Arsiparis.

Peraturan Kepala Lembaga Ilmu Pengetahuan Indonesia Nomor 2 Tahun 2014 tentang Petunjuk Teknis Jabatan Fungsional Peneliti. 